\title{
Optimization of cell motility evaluation in scratch assay
}

\author{
N. Ya. Gotsulyak, V. R. Kosach, O. V. Cherednyk, I. O. Tykhonkova, A. I. Khoruzhenko
}

State Key Laboratory of Molecular and Cellular Biology,

Institute of Molecular Biology and Genetics, NAS of Ukraine

150, Akademika Zabolotnoho Str., Kyiv, Ukraine, 03680

a.i.khoruzhenko@imbg.org.ua

\begin{abstract}
A scratch test is one of the most popular methods of classical cell migration assay in a monolayer culture. At the same time, the scratch assay has some disadvantages that can be easily corrected. Aim. Optimization the existent scratch assay on the base of detection of scratch wound surface area and the length of the field of observation which is more objective and less time consuming. Methods. Scratch assay. Results. The modification of scratch assay enables to perform measurement more accurately and rapidly. This approach is more simple and eliminates the main disadvantages of the classical method. Conclusions. The procedure of scratch wound width measurement calculated on the base of detection of cell free area and the length of the field of observation is more effective than the classical wound healing assay. It will be useful for the estimation of cell migration dynamics in monolayer culture for a wide range of live cell based experiments.
\end{abstract}

Keywords: valuation of cell migration activity, scratch assay.

Introduction. Migration is one of the most important cell functions that consists in any direction movement and results in change of the cell position within the body [1]. It plays a key role in the embryonic development, wound healing, immune response and a number of other fundamental biological processes. On the other hand, the aberrant cell migration activity is an inherent feature of many pathological processes. It accompanies malignant tumors, inflammatory, autoimmune, cardiovascular and neurodegenerative diseases [2]. Therefore, the determination of cell migration activity is one of the major tasks in many biological and medical studies. Its accuracy requires further development and improvement [3]. For a long time, Boyden chamber and scratch wound based assay were the dominant instruments in the measurements of the cell migration and invasion activity [4]. However, rapid development of the cell biology tools has led to an appearance of new approaches such as the cell exclusion zone assay, fence assay, microcarrier bead assay, spheroid migration assay, capillary chamber migration assays etc. [5]. Nowadays the

(C) Institute of Molecular Biology and Genetics, NAS of Ukraine, 2014 main efforts in this field are directed towards the development of the assay kits that can facilitate handling, improve reproducibility, give quantitative results and increase throughput [6]. Traditional methods for monitoring cell motility with their inherent high level of noise are looking very limited to obtain reliable data. However, according to the literature data, the classical methods are still prevailing over the modern approaches [7].

The scratch assay firmly established itself as popular and cheap method that is used to study cell migration in monolayer culture. The method is based on the physical separation of cell monolayer to form a cell free zone that will be filled by migration of peripherally situated cells. For this purpose, a pipette tip or syringe needle is typically used [8]. Cells migrate from intact peripheral edges into the scratched cell free zone and this process can be easily microscopically monitored. The results can be presented as a decrease in the width of uncovered region between different time checkpoints [9]. The effect of factors influencing cell migration is normally measured within a $24-\mathrm{h}$ period.

However, the main drawback of the assay consists in the inability to distinguish between the effect of cell 
proliferation and changes in cell survival, and the cell motility after period longer than $24 \mathrm{~h}[9,10]$. Besides, there are some another limitation of this system. Methods for creating of the scratches vary among different laboratories [11, 12], thus the size, shape, and spacing of the scratches are different that, in turn, will increase the level of noise [12,13]. Moreover, it is difficult to reproduce equivalent conditions of monolayer confluence between different experiments. Also the process of scratching can lead to the damage of underlying ECM (extracellular matrix components) and release factors that will change the cell migration activity and cause some experimental errors [11-13].

However, the scratch assay has some advantages: the movement and morphology of cells are visible to be observed in the real time; it is possible to measure velocity of cell migration; the assay is compatible with any plate configuration; cell movement is definitely directed; the growth surface for cell migration can be coated with an ECM [11]. The main advantages of this assay include also simplicity, rapid setup, easy readout and analysis, and, of course, its low cost.

In this report, in order to improve the classical scratch assay, we propose to perform the calculation the cell free area between outgrowing monolayers, using available Internet tool Icy 1.3.2.0 (http://icy.bioimageanalysis. org) [14]. In our modification the scratch wound width is calculated on the basis of detected cell free area and the width of the field of observation. Such approach has been applied for the analysis of MCF-7 cell motility, and migration activity of HeLa cells under the influence of paracrine factors produced by the NIH3T3 fibroblasts line.

Materials and methods. Cell culture. MCF-7, HeLa and NIH3T3 cells were cultured in DMEM medium («Sigma», USA) supplemented with $10 \%$ FBS, $4 \mathrm{mM}$ glutamine, $50 \mathrm{U} / \mathrm{ml}$ penicillin and $50 \mu \mathrm{g} / \mathrm{ml}$ streptomycin at $37{ }^{\circ} \mathrm{C}$ in $5 \% \mathrm{CO}_{2}$ humidified atmosphere. All used cell lines were tested for mycoplasma contamination.

Scratch assay. NIH3T3 cells (3000 cells in $700 \mu 1$ of DMEM/FBS) were seeded at the periphery of each well in 6-well culture plates. Cells were incubated during $1,5 \mathrm{~h}$ at $37^{\circ} \mathrm{C}$. Non adhered cells were removed by repeated washing with culture medium. After that $\mathrm{HeLa}$ cells were added to the wells in quantity of 2000 cells/ well in the complete growth medium. HeLa and NIH $3 \mathrm{~T} 3$ cells were co-cultured for $48-72 \mathrm{~h}$ before scraping the subconfluent cell monolayer by tip in order to create an experimental wound. After removing the damaged cells, the cultures were washed with DMEM complete medium. Then $2 \mathrm{ml}$ of DMEM complete medium with or without $10 \mathrm{nM}$ rapamycin were added to corresponding wells. As a result, HeLa cells, HeLa cells treated with $10 \mathrm{nM}$ rapamycin, HeLa/NIH3T3 coculture, HeLa/NIH3T3 coculture treated with $10 \mathrm{nM}$ rapamycin were incubated at $37^{\circ} \mathrm{C}$ for $24 \mathrm{~h}$. The images of 10 randomized fields of observation of each scratch were captured with a microscope just after scraping and after $24 \mathrm{~h}$ of cultivation. The size of widths and areas were determined from these images using Icy 1.3.2.0 software.

MCF-7 cells were tested in a similar manner. The migration dynamics of MCF-7 cells untreated and treated with $10 \mathrm{nM}$ rapamycin was analyzed. The width sizes of the wound were compared after $24 \mathrm{~h}$ of cultivation. The cells were fixed with methanol for $5 \mathrm{~min}$ at room temperature and stained by May-Grunvald-Giemsa method.

The cultured cells were examined using Leica DM 1000 microscope («Leica», Germany).

Statistical analysis. The data were analyzed with Student's $t$-test. The results were expressed as the mean. The differences were considered significant at $\mathrm{p}<0,01$. Each experiment was repeated 2-4 times.

Results and discussion. Standard method of cell motility analysis in monolayer culture. As it was abovementioned the wound healing test or scratch assay is often used for the evaluation of locomotor properties of the cells in monolayer culture. Our experience shows that the width of the initial scratch zone created by the pipette tip may vary considerably in the different culture dish, including controls. As a result, the expression of cells migration distance as a percentage relative to the controls cannot be absolutely adequate. So, the measurement of the absolute value of the cells migration distance is more correct. This index should be expressed as the difference between the width of wound surface just after application of scratch and after a corresponding period of cells migration.

Usually in scratch assay the average of the linear distance between the wound healing edges is analyzed. But morphological analysis of micrographs revealed 

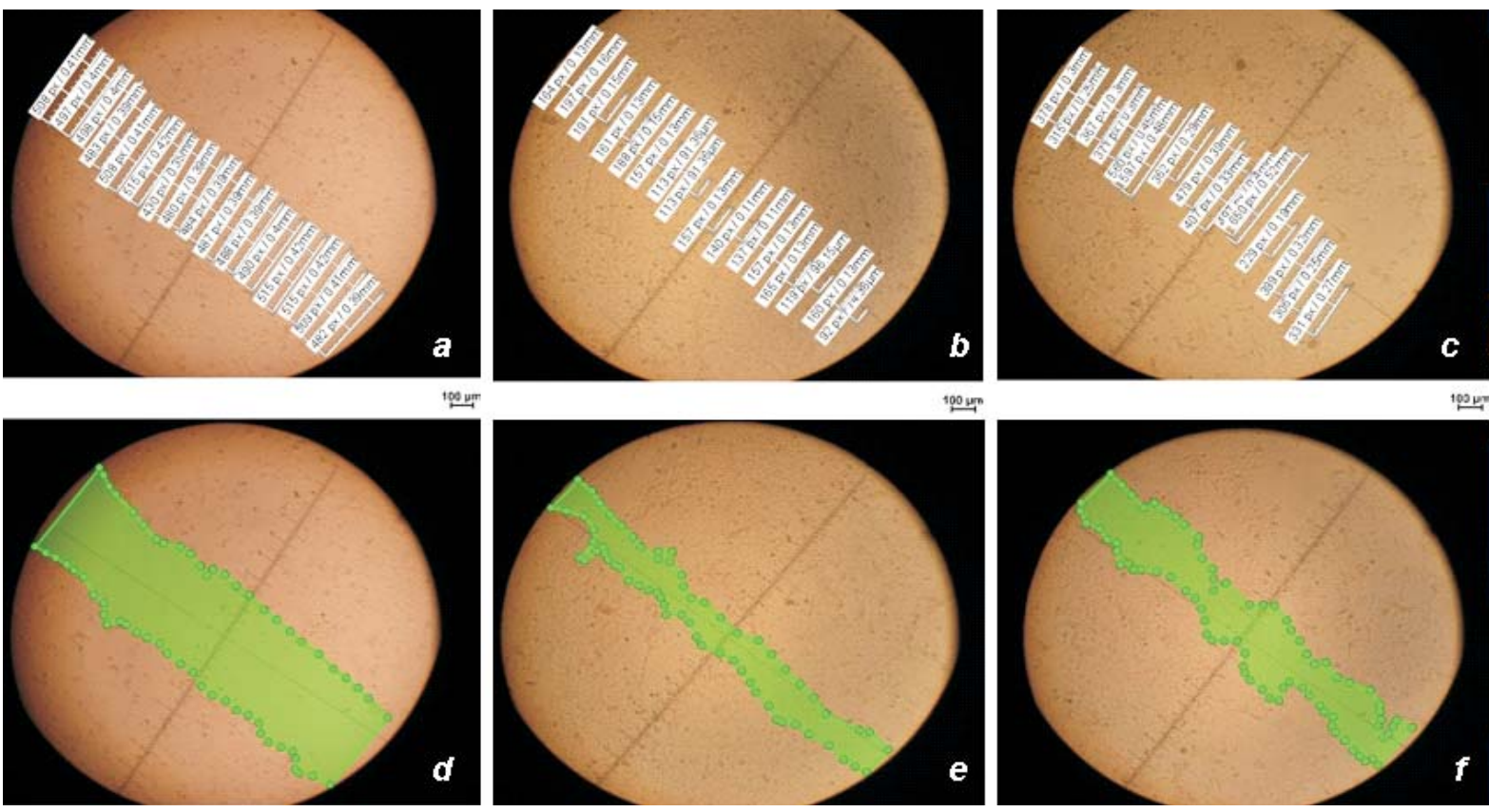

Fig. 1. Detection of the migration potential of HeLa cells using a scratch assay by routine measuring of wound surface width and the area between the edges of an experimental wound: $a$ - measurement of the width of control wound; HeLa cells just after the scratching; $b$ - measurement of the width of control wound; HeLa cells 1 day after the scratching; $c$ - measurement of the width of experimental wound; HeLa cells cocultured with NIH3T3 fibroblasts 1 day after scratching; $d$ - measurement of the area of control experimental wound; HeLa cells just after the scratching; $e-$ measurement of the area of control wound; HeLa cells 1 day after the scratching; $f$-measurement of the area of experimental wound; HeLa cells cocultured with NIH3T3 fibroblasts 1 day after scratching

that the moving edges of cell front may have ragged shape. It leads to the incorrect determination of the width of cell free zone, and significantly increases the number of necessary linear measurements. Therefore, the determination of the area between the interlocking edges of experimental wound takes into account the topography of moving layers more precisely.

There are some image analysis tools that allow performing such estimation quickly and accurately ( $\mathrm{T}$ scratch, Icy etc.) (Fig. 1).

New approach for evaluation of cell locomotor properties in scratch assay. The average distance between the migrating layers can be calculated by the method of trapezes. In this case the resulting polygon area is expressed as the sum of trapeze areas with height $(h)$ of $1 \mu \mathrm{m}$ (Fig. 2), so that the number of trapezes is numerically equal to the length of a polygon $(L)$. The sides of the trapeze are too short compared to the perimeter of the cell, so we can consider them as line segments. So, $S=S_{1}+S_{2}+S_{3}+\ldots+S_{n}$, where $S$ - polygonal area measured by the image analysis, $S_{1}, S_{2}, S_{3}, S_{n}$ - the areas of trapezes which form the polygon. The area of trapeze can be calculated using the formula: $S_{1}=h \cdot m_{1}$, where $h-$ trapeze height $(1 \mu \mathrm{m}), m_{1}$ - trapeze middle line. Thus, the average length of the trapeze midline characterizes the average distance between the layers of cells. So,

$$
\begin{aligned}
& \quad S=h \cdot m_{1}+h \cdot m_{2}+h \cdot m_{3}+\ldots+h \cdot m_{n}=h \cdot\left(m_{1}+m_{2}+\right. \\
& \left.+m_{3}+\ldots+m_{n}\right) ; \\
& \quad\left(m_{1}+m_{2}+m_{3}+\ldots+m_{\mathrm{n}}\right)=S / h ; \\
& \quad\left(m_{1}+m_{2}+m_{3}+\ldots+m_{\mathrm{n}}\right) / n=S / h L
\end{aligned}
$$

where $n$-number of trapezes, $L-$ length of polygon. As noted above, the trapeze's height $\mathrm{h}=1 \mu \mathrm{m}$, so the number of trapezes $\mathrm{n}$ is equal to the polygon length, whence it follows $m_{\text {mean }}=S / L$. Thus, the detection of the area and length of a polygon by the image analysis tool allows accurate determination of the average value of the distance between the edges of an experimental wounds. In this case, the pairs of opposite points at intervals of 1 $\mu \mathrm{m}$ will be taken into account, which significantly improve the precision of calculations.

Application of the both methods for the evaluation of migration dynamics of HeLa and MCF-7 cells. To compare the proposed approach with the routine measurement of the distance between the layers of cells, we performed an analysis of the MCF-7 and HeLa cells moti- 


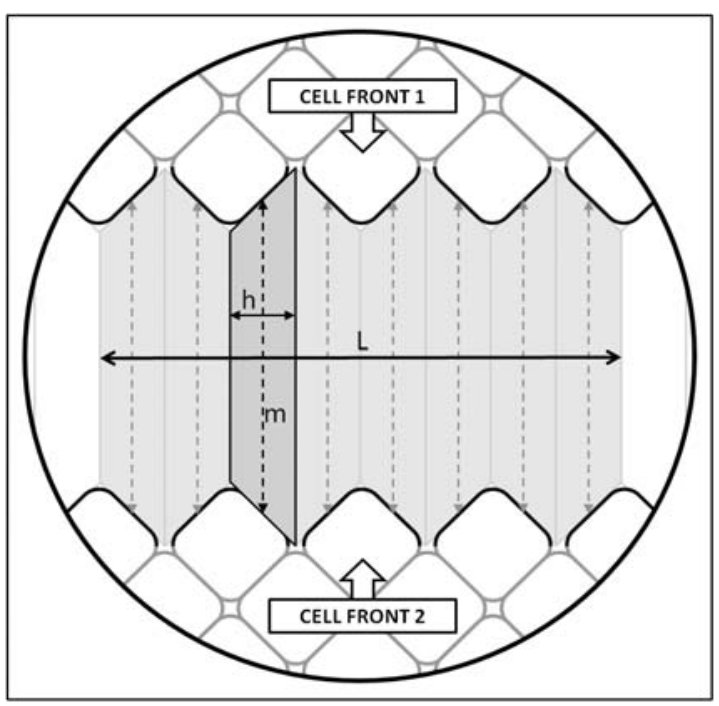

Fig. 2. Schematic representation of the experimental wound surface: dark gray area - the area of one of trapezes that forms the polygon, light gray area - the area of polygon, $h$ - the height of trapeze $(1 \mu \mathrm{m}), m-$ the middle line trapeze (dotted line), $L$ - the length of a polygon could be explained by the regulation of some mTOR substrates such as ribosomal protein S6 kinases (S6K1/2) that is aberrantly expressed in different tumor types [18$21]$ and is linked with some cytoskeleton elements [22]. Therefore, the dynamics of MCF-7 and HeLa cell migration under the influence of rapamycin has been analyzed.

To analyze the paracrine factors influence on the locomotor properties of HeLa cells, we developed our own original model. The purpose of this part of work was to determine the paracrine influence of fibroblasts (co-culture of HeLa cells with NIH3T3 cells) on the motility of tumor cells in the presence of anticancer drug rapamycin. The NIH3T3 cells were seeded strictly at the perimeter of wells of 6-well plates. After $2 \mathrm{~h}$ of incubation most of the cells adhered to the growth surface, and the unattached cells were removed by a culture medium. HeLa cells were seeded into each well. It means that only HeLa

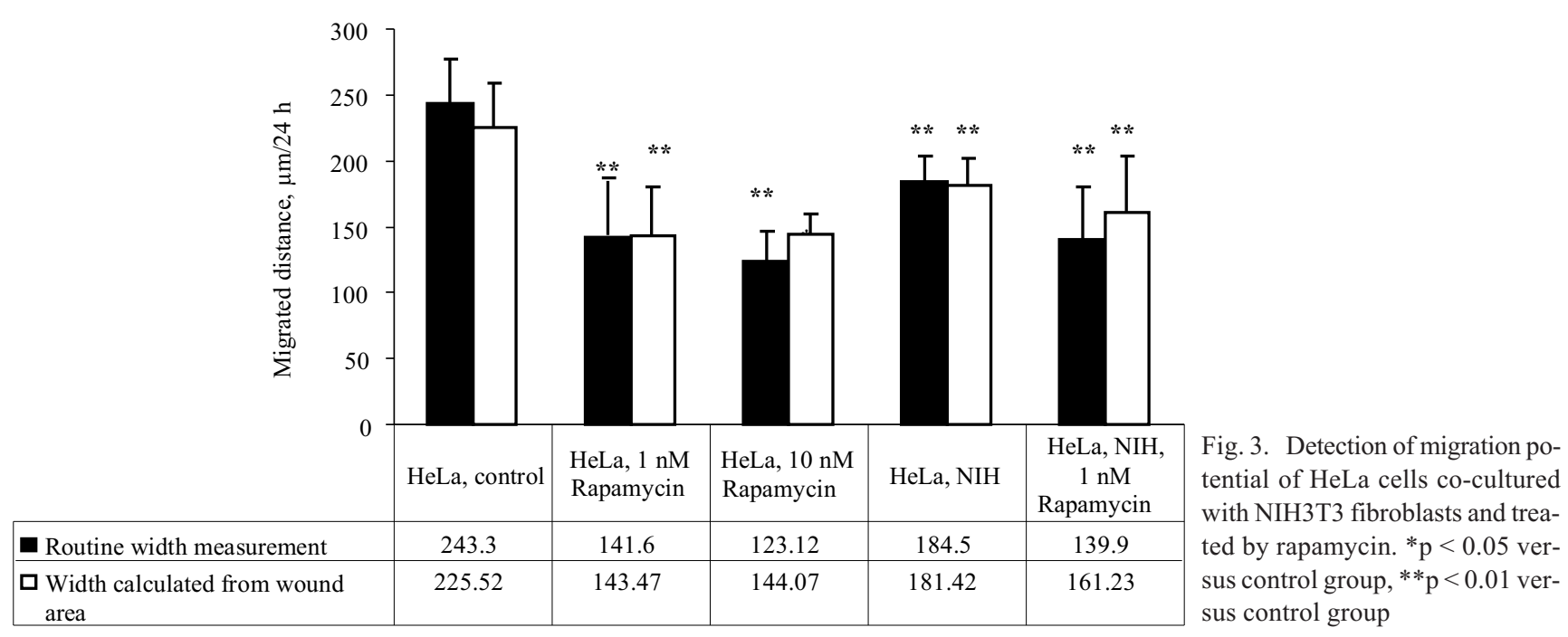

lity under the influence of paracrine factors and mTOR inhibitor rapamycin.

mTOR is a central connecting link in the signaling network that regulates the basic cellular function such as translation and transcription, and therefore, has an important impact on the regulation of major cellular function including cell migration [15]. But the exact molecular mechanisms by which mTOR regulates the cell migration remain to be determined [16]. Previously, it has been shown that modulation of mTOR activity by its specific inhibitor rapamycin resulted in a change of locomotor properties of mammalian cells [17]. In part, it cells in the center of the well (where the scratch is done) migrated on the wound surface. Thus, these cells had no direct contact with fibroblasts that ensured only the paracrine relationship. This approach allowed us to estimate the locomotor properties of HeLa cells under the conditions of co-culturing with fibroblasts and under the influence of anticancer drugs on both cell types. An analysis of the migration potential of HeLa cells showed a depressing effect of rapamycin on the locomotor properties of tumor cells, which was in agreement with a number of other studies. HeLa cells treated with $1 \mathrm{nM}$ rapamycin migrated during $24 \mathrm{~h} 100 \mu \mathrm{m}$ less than the control cells, 


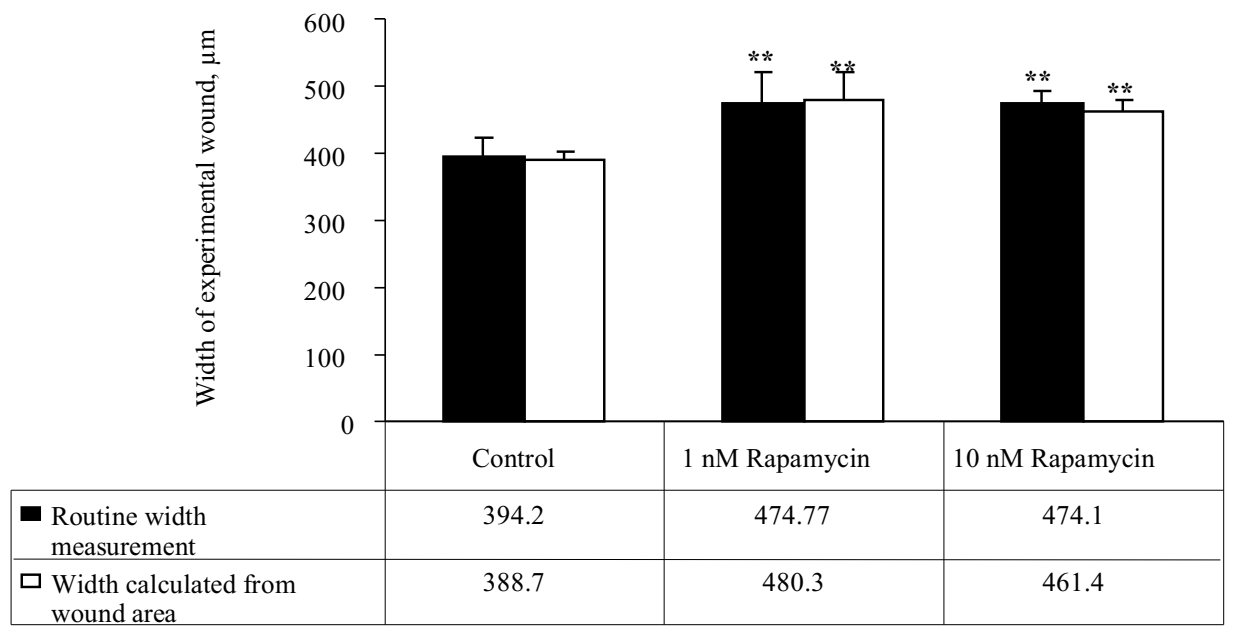

Fig. 4. Analysis of locomotor properties of MCF-7 cells treated by rapamycin. ${ }^{* *} \mathrm{p}<$ $<0.01$ versus control group at $10 \mathrm{nM}$ rapamycin treatment the cells migrated about $120 \mu \mathrm{m}$ less than the control cells. It should be emphasized that in some works the conditioned medium of NIH 3T3 fibroblasts stimulated migration of tumor cells [23]. Noteworthy that under the mutual influence of NIH3T3 and HeLa cells in monolayer culture, the migration potential of HeLa cells was slightly (but statistically significant) decreased, the cells covered the distance about $60 \mu \mathrm{m}$ less than the control cells in $24 \mathrm{~h}$. The addition of $1 \mathrm{nM}$ rapamycin to the HeLa/NIH3T3 co-culture depressed the movement of HeLa cells, to $100 \mu \mathrm{m}$ less than the control cells. As described in «Materials and methods» we used the width of wound surface for assessing the distance migrated by cells, which is reflected in the histogram (Fig. 3). Besides, the application of image analysis tool Icy [http://icy.bioimageanalysis.org] to evaluate the cell free area in scratch test just after the experimental wound creation and after $24 \mathrm{~h}$ incubation also allowed us to detect an average distance between the leading edges of opposing layers. As it can be seen from Fig. 3 , there was no significant difference between two approaches to the cell migration characterization. Notably, the standard deviations of the data obtained by two mentioned methods were very similar as well (Fig. 3).

In addition, these approaches were used to study the influence of rapamycin on the locomotor properties of MCF-7 cells. It was observed that mTOR kinase inhibitor rapamycin decreased the migration potential of tumor cells (Fig. 4). The addition of rapamycin in concentration of $1 \mathrm{nM}$ and $10 \mathrm{nM}$ slowed up the MCF-7 cell locomotion to $70-90 \mu \mathrm{m}$. The average distances bet- ween the edges of experimental wound detected by the routine measurement and the cell free area detection were very similar. As in the previous case, the standard deviation values of data obtained by two different approaches were very similar as well.

In the present study, two approaches for the evaluation of scratch assay data on the determination of cell migration dynamics in monolayer culture have been compared. The first one is based on the direct measurement of the distance between the edges of experimental wound. The second one implies the initial determination of the cell free area for calculation of an average width of the experimental wound. It was revealed that both approaches are able to determine the same characteristics of the cell motility. Thus, we have proved the adequacy of the second approach, which is theoretically more accurate and practically is easier to assess the locomotor properties of the cultured cells in wound healing test.

Оптимізація оцінки міграційного потенціалу клітин методом «раневої поверхні»

Н. Я. Гоцуляк, В. Р. Косач, О. В. Чередник, І. О. Тихонкова, А. І. Хоруженко

Резюме

Метод «раневої поверхні» є одним з найпоширеніших методів класичного аналізу міграиії клітин у моночаровій культурі. Водночас, метод "раневої поверхні» має деякі недоліки, які можуть бути легко відкориговані. Мета. Оптимізаиія існуючого методу «раневої поверхні» на основі визначення площі поверхні рани і ширини поля зору, що є більш об 'єктивним і менш часозатратним. Методи. Локомоторну активність клітин оцінювали за мето- 
дом «раневої поверхні». Результати. Модифікація методу «раневої поверхні», представлена в статті, дає можливість отримувати більш точні дані. Практично цей підхід набагато простіший та усуває основний недолік зазначеного методу. Висновки. Прочедура вимірювання ширини раневої поверхні, розрахованої на основі визначення площі, не зайнятої клітинами, і ширини поля зору, є значно ефективнішою, ніж класичний аналіз міграиійного потенціалу клітин за методом «раневої поверхні». Така модифікація буде корисною для оцінки динаміки міграції клітин у моношаровій культурі для широкого кола експериментів, які передбачають використання живих клітин.

Ключові слова: оцінка міграџійної активності, метод "раневої поверхні».

Оптимизация оценки миграционного потенциала клеток методом «раневой поверхности»

Н. Я. Гоцуляк, В. Р. Косач, О. В. Чередник, И. А. Тихонкова, А. И. Хоруженко

Резюме

Метод «раневой поверхности» является одним из наиболее распространенных методов классического анализа миграции клеток в монослойной культуре. В то же время метод «раневой поверхности» имеет некоторые недостатки, которые могут быть легко откорректированы. Цель. Оптимизачия сущчествующего метода "раневой поверхности» на основе определения площади раневой поверхности и ширины поля зрения, что является более объективным и менее затратным во времени. Методы. Локомоторную активность клеток оценивали по методу «раневой поверхности». Результатьл. Модификация метода «раневой поверхности», представленная в статье, дает возможность получать более точные данные. Практически этот подход гораздо более простой и устраняет основной недостаток указанного метода. Выводы. Процедура измерения иирины раневой поверхности, рассчитанной на основе определения площади, не занятой клетками, и ширины поля зрения, является более эффективной, чем классический анализ миграционного потенциала клеток по методу «раневой поверхности». Такая модификачия будет полезной для оченки динамики миграции клеток в монослойной культу ре для широкого спектра экспериментов, предусматривающих использование живых клеток.

Ключевые слова: оценка миграционной активности, метод «раневой поверхности».

\section{REFERENCES}

1. Friedl $P$, Wolf K. Plasticity of cell migration: a multiscale tuning model. J Cell Biol. 2010;188(1):11-9.

2. Horwitz R, Webb D. Cell migration. Curr Biol. 2003;13(19): R756-9.

3. Vanderlei B, Feng JJ, Edelstein-Keshet L. A computational model of cell polarization and motility coupling mechanics and biochemistry. Multiscale Model Simul. 2011;9(4):1420-1443.

4. Hulkower KI, Herber RL. Cell migration and invasion assays as tools for drug discovery. Pharmaceutics. 2011;3(1):107-24.

5. Kramer N, Walzl A, Unger C, Rosner M, Krupitza G, Hengstschlager $M$, Dolznig $H$. In vitro cell migration and invasion assays. Mutat Res. 2013;752(1):10-24.
6. Cell Migration Assays Trends 2012: Report. Cambridge, HTS tec Limited publ. 2012; 50 p.

7. Comley J. Cell Migration: probing cell movement with smarter tools. Drug Discovery World Winter 2012/13; 14:33-51.

8. Liang CC, Park AY, Guan JL. In vitro scratch assay: a convenient and inexpensive method for analysis of cell migration in vitro. Nat Protoc. 2007;2(2):329-33.

9. Rodriguez LG, Wu X, Guan JL. Wound-healing assay. Methods Mol Biol. 2005;294:23-9.

10. Yarrow JC, Perlman ZE, Westwood NJ, Mitchison TJ. A highthroughput cell migration assay using scratch wound healing, a comparison of image-based readout methods. BMC Biotechnol. 2004;4:21.

11. Vogt A. Advances in two-dimensional cell migration assay technologies. Eur Pharm Rev. 2010;5:26-29.

12. Kam Y, Guess C, Estrada L, Weidow B, Quaranta V. A novel circular invasion assay mimics in vivo invasive behavior of cancer cell lines and distinguishes single-cell motility in vitro. BMC Cancer. 2008;8:198.

13. Staton $C A$, Reed $M W$, Brown NJ. A critical analysis of current in vitro and in vivo angiogenesis assays. Int J Exp Pathol. 2009;90 (3): $195-221$.

14. de Chaumont F, Dallongeville $S$, Chenouard N, Herve N, Pop S, Provoost T, Meas-Yedid V, Pankajakshan P, Lecomte T, Le Montagner Y, Lagache T, Dufour A, Olivo-Marin JC. Icy: an open bioimage informatics platform for extended reproducible research. Nat Methods. 2012;9(7):690-6.

15. Filonenko $V V$. PI3K/mTOR/S6K signaling pathway - new players and new functional links. Biopolym Cell. 2013;29(3):207-14.

16. Liu L, Parent CA. Review series: TOR kinase complexes and cell migration. J Cell Biol. 2011;194(6):815-24.

17. Gillen JR, Zhao Y, Harris DA, Lapar DJ, Stone ML, Fernandez $L G$, Kron IL, Lau CL. Rapamycin blocks fibrocyte migration and attenuates bronchiolitis obliterans in a murine model. Ann Thorac Surg. 2013;95(5):1768-75.

18. Filonenko VV, Tytarenko R, Azatjan SK, Savinska LO, Gaydar $Y A$, Gout IT, Usenko VS, Lyzogubov VV. Immunohistochemical analysis of S6K1 and S6K2 localization in human breast tumors. Exp Oncol. 2004;26(4):294-9.

19. Lyzogubov V, Khozhaenko Y, Usenko V, Antonjuk S, Ovcharenko $G$, Tikhonkova I, Filonenko $V$. Immunohistochemical analysis of Ki-67, PCNA and S6K1/2 expression in human breast cancer. Exp Oncol. 2005;27(2):141-4.

20. Lyzogubov VV, Lytvyn DI, Dudchenko TM, Lubchenko NV, Pogrybniy $P V$, Nespryadko $S V$, Vinnitska AB, Usenko VS, Gout IT, Filonenko $V V$. Immunohistochemical analysis of S6K1 and S6K2 expression in endometrial adenocarcinomas. Exp Oncol. 2004; 26(4):287-93.

21. Savinska LO, Lyzogubov VV, Usenko VS, Ovcharenko GV, Gorbenko ON, Rodnin MV, Vudmaska MI, Pogribniy PV, Kyyamova RG, Panasyuk GG, Nemazanyy IO, Malets MS, Palchevskyy SS, Gout IT, Filonenko VV. Immunohistochemical analysis of S6K1 and S6K2 expression in human breast tumors. Eksp Onkol. 2004;26(1):24-30.

22. Fenton TR, Gout IT. Functions and regulation of the $70 \mathrm{kDa}$ ribosomal S6 kinases. Int J Biochem Cell Biol. 2011;43(1):47-59.

23. Kirui JK, Xie Y, Wolff DW, Jiang H, Abel PW, Tu Y. Gbetagamma signaling promotes breast cancer cell migration and invasion. J Pharmacol Exp Ther. 2010;333(2):393-403. 